\title{
Futures Studies: Spirituality in the Cosmic Man
}

\author{
Halyna Shevchenko \\ Doctor of Pedagogical Sciences, Professor, Academician of the NAES of Ukraine, \\ Volodymyr Dahl East Ukrainian National University \\ (Severodonetsk, Ukraine) \\ E-mail: shevchencko.gala@gmail.com \\ ORCID: 0000-0002-3438-2858
}

\section{Tetyana Antonenko}

PhD, Associate Professor, Volodymyr Dahl East Ukrainian National University

(Severodonetsk, Ukraine)

E-mail: tl.antonenko@gmail.com

ORCID: 0000-0001-7588-382X

Today's crisis of education should be considered as a crisis of a moral and spiritual basis of our society. Upbringing and education are a kind of spiritual activity, an important component of spiritual culture. Thanks to upbringing and education, a person improves himself intellectually, mentally, morally, artistically, aesthetically, spiritually, acquires the image of the Man of Culture. The crisis of the educational system is an integral part of the global spiritual crisis that has embraced society. Pedagogical science needs now a careful study of the multidimensionality and multiplicity of a person, the understanding of its true essence on the basis of a new methodology of knowledge of a unified and holistic world.

Keywords: spiritually, spiritual creativity, spiritual values, spiritual crises, cosmocentrism, cosmic man, cosmoplanetary, human creativity

Received: March 8, 2018; accepted: May 13, 2018

Philosophy and Cosmology, Volume 21, 2018: 123-130

DOI: $10.29202 /$ phil-cosm/21/13

\section{Introduction}

Today, the devaluation of the spiritual and cultural values has significantly influenced an increase in spread of the brutal individualism, the pragmatism of high and mighty attitude towards others and humiliation of their human dignity, contempt for native culture and historical and cultural traditions. Modern information and technological civilization gradually devalues the spiritual and cultural value of upbringing and education, replacing

(C) Shevchenko, Halyna, 2018

(C) Antonenko, Tetyana, 2018 
them with the acquisition of life experience from films that have dubious spiritual, moral, artistic, and aesthetic values, various shows, and education is easily acquired through the use of the Internet. This leads to the creation of a dangerous situation of separation of knowledge from the education of a person. Modern technologies intensify the processes of alienation of knowledge, marked by the experts already, including the educational activities. Mechanical technological procedures devalue the significance of a person's place in education. All this exacerbates the problems of upbringing of Man, Humanity, and Spirituality. It is our time to become the time of the Resurrection of Spirituality, Culture, and Purity of Soul.

It should be noted that an educated, but not a well-bred man, having no formed general human and national values, is dangerous to society. Upbringing and education are a kind of spiritual activity, an important component of spiritual culture. Upbringing and education carry out the mission of human creativity, cultural creativity, and spiritual creativity in the society. We consider education as a process for students' acquisition of the system of spiritual and cultural values, which are a guiding light in the selection and implementation of life-oriented ideals; as a sense basis of education, which is the source of the intellectual development of a person, who develops his intellect through science, culture and the criticality of thinking, reflection, participation in various forms of creativity. The process of upbringing appears to be dominant in this set. Thanks to upbringing and education, a person improves himself intellectually, mentally, morally, artistically, aesthetically, spiritually, acquires the image of the Man of Culture [Shevchenko, 2017].

\section{Methodological Framework and Objectives of the Study}

Pedagogical science as a branch of human studies needs now a careful study of the multidimensionality and multiplicity of a person, the understanding of its true essence on the basis of a new methodology of knowledge of a unified and holistic world [Bazaluk \& Blazhevych, 2015; Bazaluk, 2018]. It is clear that and methodology, and theory, and practice of education are determined by the nature of man in his age formation, and in general — the evolution of mankind.

Despite all the efforts of the world pedagogical community to raise the level of education in society, it decreases with each passing year. Centers, institutes of perfection, harmony and beauty of a person turn into centers of preventive education, rehabilitation of groups of risk, etc. For millennia, the brightest heads of the world have been struggling with the issues of upbringing of a humane, beautiful, God-like man. Today, as ever, Oleksandr Klyzovsky's opinion that the material crises in the society are directly related to the spiritual crises is current: "... the education of humanity has removed the main lever of perfection, the main factor in the development of life - the upbringing of the spirit. Mankind is experiencing an unprecedented crisis, precisely because of the stoppage of its development, because of the loss of its spiritual values. Economic impoverishment is the result of impoverishment of the spiritual" [Aleksandrov, 1999]. It is not superfluous to emphasize here that these words, which so clearly reflect the state of our contemporary society, were prophetic. After all, the author formulated them during the crisis that arose in Latvia in 1934. It would be possible to cite many similar thoughts, which were expressed at different historical stages.

Take at least the $30^{\text {th }}$ century BC. In ancient Babylonia there is an inscription on the clay crockery, full of sorrow and disappointments: "This youth is corrupted spiritually to the depths of the soul. Young people are harmful and careless ... The young generation of the present will not be able to preserve our culture", but the main thing is that the problems of spirituality, breeding, and high culture of the individual are eternal. 
In recent years, the problems of spirituality have occupied a prominent place in the various fields of knowledge, because they bring us closer to the disclosure of the eternal mystery — the man's ambiguity, its true essence.

The anthropocentric, materialistic worldview (claimed from the seventeenth century and, in accordance with it, the paradigm of analytical and pragmatic cognition and the development of the world) created the modern technocratic civilization, which led to the fatal distribution of knowledge on natural sciences and humanities, to the typology of sciences about nature and spirit, on traditional separation of the integrated knowledge on separate disciplines in the secondary school already, that is, to the discoordination of different areas of knowledge [Vilkov, 2018].

Such a substantive approach in education of all degrees poses a threat to pragmatism and utilitarianism, the fragmentation of knowledge, its lack of system, separation, and isolation from one another. In the content of modern education, most educational subjects are oriented, mainly to "subjugation of nature", the world, and not to cooperation, interaction with them; and knowledge, as it is known, depending on the "carrier of knowledge", can be used both on the processes of creation, and consumption or destruction. Moreover, the domination of materialism and polytechnicalism has pushed aside the spiritual and humanitarian knowledge that forms the soul-spiritual hypostasis of Man, his inner world that affects the spiritual development of a personality and a society negatively [Tytarenko, 2018]. Another important problem of the modern education is that traditional pedagogy, understanding a person as a biosocial creature and ignoring its spiritual component completely, interpreted a person not as a bio-socio-spiritual phenomenon, but only as an earthly being, a distinct living structure that is not interrelated with the world, leading to disharmony, a violation of harmonious relationships with the information and energy space. Today a person, unfortunately, does not realize himself as the complex bio-energetic information system that is a part of the world: the Earth, the society, the Universe, with which he is in a stable information and energy interaction. The consequence of this is the loss of a person's need for knowledge of himself and the world, the lack of desire to understand his mission and purpose on the Earth, responsibility "for the world and for himself in the world." Having lost a sense of involving, belonging to the world, mankind did not form responsibility for the life on the Earth and in the Cosmos and came to be in the "space" of the pernicious process of moral, spiritual and environmental self-destruction. Today, scholars are deeply concerned about the fact that the high ontological and existential goals are not raised in today's school, schoolchildren are not taught the ability to create their lives, proper attention is not paid to the problems of spiritual self-knowledge, self-development and self-realization, which leads to the formation in the younger generations of consumer psychology, upbringing of a technocratic man, a humandestroyer, a non-spiritual person, and not a creator. According to Alla Kuznetsova, today's crisis of education should be considered as a crisis of a moral and spiritual basis: proclaiming of high humanistic principles and goals and ignoring them in practical activity, lack of spirituality of participants in the educational process, irresponsibility in decision-making, ignoring the personality in the educational process and the lack of spiritual component in the goals and content of education [Kuznetsova, 2012: 139-52]. Despite the proclaimations in the normative documents of slogans of human centered education about the self-worth and uniqueness of each person, the importance of maximum disclosure and development of the desires, spiritual needs and interests of each child, the education system, which developed in the $19^{\text {th }}$ - the first half of the $20^{\text {th }}$ century, is oriented mainly on the reproductive type of education, training intellectuals Modern education of all levels does not pay proper attention 
to the moral and spiritual education, disclosure and development of the creative potential of the individual, as evidenced by a sharp decline in the moral and ethical potential of education. Today, the state of education all over the world has collapsed, that is testified by the "systemic crisis on the planet", which includes the general crisis of education, which was recorded by the Roman club in the 1970's [Peccei, 1997: 302]. According to the modern scholars, the crisis of the educational system is an integral part of the global spiritual crisis that has embraced society [Shevchenko, 2017].

In the cognition, the model of subjective and objective opposition prevailed, which turned out to be a special form of the gap between Man and the World, and which for a long time remained unconditional and the only form of explanation for the world. This led to the consumers' attitude towards the world, mechanistic understanding of the relationship between Nature and Man, and generated patterns of interaction between Man, Nature, Society and State, which contribute to the destruction of the biosphere and the degradation of Man.

The famous scholars of physics and cosmology (David Bom, Paul Davis, Fritjof Capra) form a new paradigm of human knowledge as a biological, social and cosmic being on the basis of a holonomic approach to the world and a holistic view of the Universe.

A new model approach to the knowledge of a single and holistic world, on which the philosophical picture of the cosmic phenomenon of man is constructed, attracts attention. Ihor Alexandrov [Klizovsky, 1998], sharing the view of Man as a cosmopolitan phenomenon of Pierre Teilhard de Chardin, as well as their ideas of the integrity and unity of nature and space, emphasizes a specific feature of a new stage in the development of land civilization, the essence of which he saw in the change of human worldview: from the ideas of anthropocentrism to cosmocentrism. It intensifies the attention to the study of the deep essence of Man, whose nature is extremely controversial and multifaceted. In view of these features, it is possible to design a program of 'cultivating human perfection'. By the way, Jan Amos Komensky in his work "On the culture of natural talents" wrote, "Look at the precious stone that shines radiantly in the royal crown or on the princely fingers. Do you think so it was born? You are mistaken, when you think so. It was born rough, dark, and dirty; you would not raise it from the ground. In order for it to shine, it is necessary to clean it, to saw it, to smooth it, to trim it, to file, and to polish." Let us add to this that the master must know the features and the secret power of the stone. Let us recall Danila-Master from Bazhov's story. Let us emphasize once again that taking into account the latest knowledge about Man enables pedagogical science to reconsider many pedagogical phenomena, to depart from stereotypical views on learning, formation, development of personality.

Let us consider human diversity and contradictions, the essence of which is manifested in the unity and multiplicity of the opposite qualities, such as materiality and spirituality, spirituality and lack of spirituality, rationality and irrationality, consciousness and unconsciousness, etc. [Klizovs'ky, 1998]. We consider Klizovs'ky opinion about three necessary directions of knowledge of the integral essence of the complex phenomena of the human world to be very fruitful:

1. The study of a separate and solid hierarchical plurality of human properties, its diversity;

2. The study of the cosmic nature of Man, understanding of space and man in the unity and integrity of the spirit, mind, consciousness, matter and life;

3. Study of the unity and integrity of the world, in which Man acts as the active force.

Scholars relate spirituality, intelligence, consciousness, activity, psychologicalness, symbolicalness, creativity, and sophisticalness (wisdom) to the main forms of manifestation 
of the true essence of Man in the modern philosophical and psychological literature. Pierre Sharron, a well-known French philosopher-moralist, a theologian of the $16^{\text {th }}-17^{\text {th }}$ centuries, noted that wisdom is not knowledge brought by someone else, but its ordering for the "convenient" use. We understand only ourselves. If something else succeeds other people in relation to us, it just wakes up that which is sleeping in us [Shevchenko, 2017].

The most important factor in improving the nature of Man is his cognitive, objective, creative activity, communication, learning, games, work, and creativity. The "second" nature of Man is being polished and born just in the activity. The more diverse participation of the individual in different activities is, the higher his creative potential is, the more harmonious, spiritualized, integral his inner world is. In the activity the worldview, and the spiritual needs of the individual, and the essence of his individual evolution, and personal contribution to the evolution of the mankind are captured. There is a classic example of a Georgian fairy tale about this. The Tsar of Georgia fell in love with the daughter of the goldsmith and asked for her hand in marriage. Moreover, what his surprise was when the bride's father asked him, "What can you do? What kind of craft do you have in your hands? What is the business you have mastered? To issue orders and decrees is not something that glorifies a person and raises him on the stage of the earthly value!" The Tsar had to pass the science of mastering the art of chasing, to become the Real Master - the Creator and worthy husband of the daughter of the Great Master. Even this example gives an opportunity to see the correct way of forming the multiplicity and cultural essence of a person - a way of tireless work of spirit, mind, consciousness, psyche, and creativity. Recall the words of Jesus: "Faith is dead without works." Consequently, work, respect for Man-Master in the conditions of the new market relations in our state should take a worthy place in the pedagogical researches, because activity in all its varieties is a ray in which all spiritual values of Man, hopes of the mankind are focused. We should remember that each nation has its own mentality. For the mentality of the Ukrainian people, the desire to create beauty of the environment and the surrounding reality, love for work is a national feature, an archetype of the Ukrainian culture. That is why activities on the creation of the external and inner world are always shrouded in beauty, high moral virtues, harmony and high spirituality.

Understanding the essence of spirituality can help to look at a person as a cosmopolitan phenomenon. Ancient myths, historical and cultural monuments testify to the fact that Man is the essence of the heaven and the Earth. In the $4^{\text {th }}$ century BC Hermes Trismegistus ("three times the greatest") in his "Emerald Tables of History" formulated the idea: "The globe is rolling, and it will never be possible to establish where the beginning of any story takes place in the heaven or on the Earth. Only that one serves the truth who claims that all of them are performed/played accordingly and simultaneously here and there, and it seems only to our eye as if they fall and rise again. But what happens underneath, and could not have happened, it, so to speak, would not have lighted upon to oneself without his heavenly pattern and likeness."

The views on space and life belonging to Volodymyr Vernads'ky, Kostyantyn Tsiolkovs'ky, Oleksandr Chyzhevs'ky, and Ihor Alexandrov, who affirmed that the fate of a person depends on the destiny of the Universe, that life is more a cosmic phenomenon than the earthly one, that life comes from space, and its code is recorded on the earth, are the continuation of this thought [Bazaluk, 2016]. The cosmic essence of Man is determined by the Cosmic Absolute, which has given the birth to Man just as itself in the form of a system of microcosm, and Cosmos, which affects it with its rhythms and laws of development.

The source of the development of the true essence of Man is the Universe, the driving force - Cosmos and Man, the prerequisite — the Cosmic Absolute. From the point of view of 
the cosmoplanetary essence of Man, his development is determined by the living nature, the Universe, Cosmos and the Cosmic Absolute, which, on the basis of integrity, harmony, and spirituality, create a single environment rich in information. That is, the total essence of man is formed by Cosmos: everything in Man is also in Cosmos. Therefore, Man possesses the ability to self-construction, self-creation, synergeticness - the ability of self-improvement, to merge with God.

Pedagogy cannot ignore the predictions of cosmic philosophers about the interaction of life and man associated with the emergence of a new form of Life (above "Super Life") (Pierre Teilhard de Chardin), and the transition of Man (humanity) into one whole type of radiation energy [Krymsky, 1992: 21-22]. When Vlayl Kaznacheyev expresses the hypothesis of the emergence of life on the Earth as a result of "marital relations" of the space meeting on the Earth of various forms of cosmic life - protein nucleic and field, he leads us to the conclusion that the modern mankind is the unity of terrestrial and cosmic forms of life, it becomes clear the significance of the Spirit in the life, human creation of life. People say when their spirits are low, "Do not lose courage, do not lose heart"; "Strong in Spirit is indestructible, persistent, meaningful" that means to put into motion one's inner forces mind, consciousness, self-consciousness, creativity, subconsciousness, wisdom, goodness, beauty, and every day strive to rise, eulogized above existence, realize oneself in the world and the world in oneself as a ray passing through the heart.

We share the point of view of one of the leading scholar-philosophers Ludmyla Bujeva about the essence of spirituality as a problem of gaining sense, the existence of a certain hierarchy of values, goals and meanings, the constant ascension to the heights of the highest values and their realization in the practical activity. However, these are just some of the milestones that indicate a possible way to study spirituality in pedagogy.

Из мужества борцов,

Из крови битв,

Из страданий одиночества,

Из жертвенных деяний народа

Возрастет духовный плод,

Если души духовно и сознательно

Обратят свои чувства и помыслы

К Царству Духа.

Рудольф Штайнер
From the courage of the fighters,

From the blood of the battles,

From the sufferings of loneliness,

From the sacrificial deeds of people

The spiritual fruit will grow,

If souls will send their feelings

And thoughts spiritually and deliberately

To the Kingdom of Spirit.

Rudolf Steiner

As for the goal of modern education, it gradually, veiled shifts from the formation of a spiritual and moral person to the development of a successful person, "knowledgeable man", interested, mainly in obtaining the knowledge and skills that will help him to make a career and self-assertion in the society.

In modern education, the importance of informatization and computerization in society is declared, but the ideological function of knowledge (outlook) is forgotten, as a result of which the basic ideological meaning of education is lost.

Unfortunately, the modern school unilaterally relies on a materialist outlook that does not focus on the Volodymyr Vernadsky's Noosphere Concept of the whole Unity, the Laws of the World and Society, a deep understanding of these Laws, which should become the basis of the outlook and constructive activity of a modern man. 
Perhaps, therefore, we are talking about the most powerful crisis in our technocratic, globalizing world associated with education. It is difficult not to agree with Moisey Kagan, "The deep meaning of the problem of globalization is not technological, but - pedagogical." At one time, Vyacheslav Lipinsky said, "Babylon plummeted and old Rome perished, because its material technology has evolved its social morality" [Lypynsky, 1995: 204; Kagan, 2005].

The overcoming of the global spiritual crisis and ensuring the further existence of the humanity as a whole is seen by the world community in changing the paradigm of the civilization towards the co-evolution of Man, society and nature, in changing the consciousness of people, the formation of the new ideological landmarks and moral values, education of Man as a biosocial and spiritual phenomenon. And in this process, the main place, undoubtedly, belongs to education, which, being one of the basic social institutions of modern society, is an important factor in the development of the civilization. The analysts connect people and their coming out of the global systemic crisis just with education.

According to many modern scholars one of the ways to overcome the crisis of education is a noospherization of education, the relevance of which is related to the awareness of the need to rethink the laws of human life on the Earth, the character of the relations of man, nature, society and the Universe [Bazaluk \& Blazhevych, 2015; Bazaluk, 2015].

The important tasks of the noosphere education are:

1. The construction of an ecocentric or anthropocosmic worldview oriented to the harmonious partnership between man and the world;

2. In the gradual formation of a new noospheric man - the Earthman of the $21^{\text {st }}$ century, a spiritual and moral person with a holistic worldview, a noosphere consciousness, a harmonious type of thinking as the result of the combined work of the cerebral hemispheres, which will lay the foundation of the noospheric civilization of the future.

\section{Conclusions}

Thus, in our opinion, solving the problem of overcoming the crisis in the modern education will become possible under the condition of changing the consciousness of a modern person from technocratic to a spiritual, anthropocentric, materialistic outlook on the noosphere through a noospheric education aimed at forming a creative, high-spiritual personality with the deep, internal need for self-knowledge, self-development, self-improvement, selfrealization, Citizen of the World, a responsible and highly educated person, who seeks to understand the meaning and purpose of his life, to live in harmony with oneself and the world. Aurelio Peccei, the founder and president of the Rome Club, noted rightly, "If we want to change the world, we must first change the person" [Peccei, 1997: 302]. As it has been already noted, an important part of the noospheric education is the moral and spiritual component, which in the $21^{\text {st }}$ century got the global meaning in the world, since the level of spirituality, humanization and democratization of the terrestrial society as a whole depends on the level of spiritual development of each one.

\section{References}

Aleksandrov, Igor. Kosmichesky fenomen cheloveka: chelovek v antropnom mire. Moscow: Agar, 1999.

Bazaluk, Oleg. The Feature Transformations of the Basic Meanings of Greek Paideia in the Educational Theories in the Middle Ages. $\mathrm{XX} \Lambda \mathrm{H}$ (Schole), Vol. 12.1, 2018: 243-258. DOI: $10.21267 / A Q U I L O .2018 .12 .10428$. 
Bazaluk, Oleg. The Theory of Evolution: From a Space Vacuum to Neural Ensembles and Moving Forward. Newcastle upon Tyne: Cambridge Scholars Publishing, 2016. — 170 p.

Bazaluk, Oleg, and Tamara Blazhevych. Modern Basics Philosophy of Education. Future Human Image. 2 (5), 2015: 93-100.

Kagan, Moisey. Globalizatsiya kak zakonomernost' protsessa razvitiya chelovechestva. Problemy teorii I istorii kul'tury: issledovaniya i materially. Orenburg: $O G P U$, Vyp.1, 2005.

Klizovsky, Aleksandr. Osnovy miroponimaniya novoy epokhi. Minsk: “Vida-N”, 1998.

Krymsky, Sergey. Kontury dukhovnosti. Novyye konteksty identifikatsii. Voprosy filosofii. № 12, 1992: 21-22.

Kuznetsova, Alla. Noosfera. Noosferna (evolyutsiyna) osvita: zavdannya i printsipy yikh realizatsii. Dukhovnist'osobystosti: metodolohiya, teoriya i praktyka. Lugans'k: Vyd-vo SNU im. V.Dalya, Vyp. 5 (52), 2012: 139-52.

Lypynsky, Vyacheslav. Lysty do brativ-khliborobiv. Tvory. Kyyiv-Filadel'fiya, T.6., 1995: 204.

Peccei, Aurelio. Chelovecheskiye kachestva. Moscow: Progress, 1997: 302.

Shevchenko, Galyna. The Ideal Image of a Man: the Main Characteristics and Ways of Achievin. Future Human Image. Volume 7, 2017: 120-127.

Tytarenko, Vadym. Correlation between Morality and Religion in Ukrainian Society: Productive Ideas in German Idealism for Modern Consideration. Ukrainian Policymaker, Volume 2, 2018: 41-47.

Vilkov, Vyacheslav. "Scientific Communism" and the Modern Political Science in Ukraine. Ukrainian Policymaker, Volume 2, 2018: 48-55 